\section{World Health Assembly votes not to destroy smallpox virus}

Janice Hopkins Tanne New York

The world's two remaining stocks of smallpox virus, kept in Russia and in the United States, should not be destroyed just yet, the World Health Assembly decided last week at its meeting in Geneva. Scientists may be allowed to genetically manipulate fragments of the virus to evaluate new drugs and treatments.

Smallpox was eradicated 25 years ago. Because vaccination stopped, many people lack immunity to the virus. Smallpox kills about a quarter to a third of those infected and leaves many survivors scarred or blind.

Both the United States and Russia spoke in favour of keeping the virus and extending the research period, but experts are concerned. Dr Georges Benjamin, head of the American Public Health Association, said, "This is a disease that doesn't exist anywhere in the world.
Nobody would want it to get out of the lab accidentally. The only rational reason [to do research] is if there's a re-emergence of the disease ... It would take a lot to convince me that it's a good thing to do research and keep the virus." Dr Benjamin said he thought the chance that there was smallpox virus outside the two repositories was "not zero, but low."

However, Dr John Deutch, former director of the US Central Intelligence Agency and now a professor at the Massachusetts Institute of Technology, said-as he recently told a Senate subcommittee- that everyone in the United States should be vaccinated against smallpox "because of the threat of a bioterrorist attack ... There's a reasonable chance that smallpox virus is out there, uncontrolled."

A national vaccination programme in the US aimed at healthcare workers and "first responders" began in 2003, but concern over side effects slowed the project's progress (BMJ 2004;328:1220).

WHO will stockpile smallpox vaccine in Geneva for use in an emergency. About 2.5 million doses are stored, and another 31 million doses have been donated, including 20 million

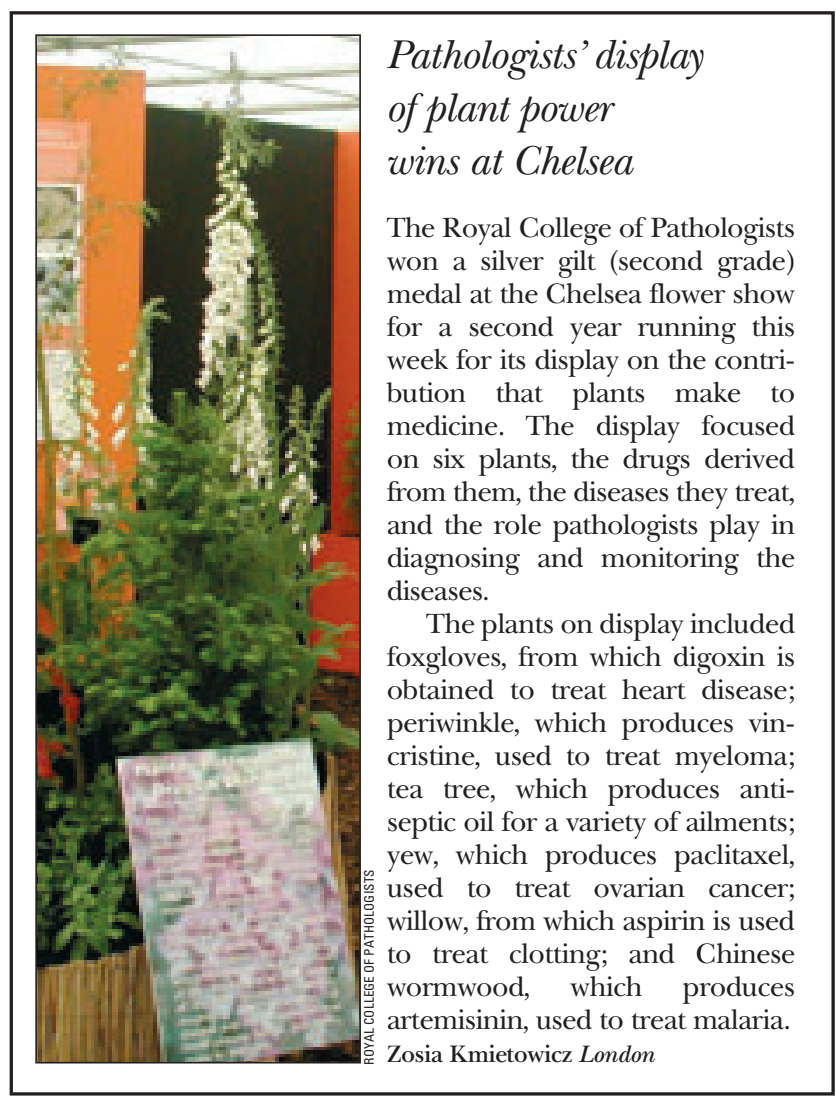

from the United States and five million from France. Reuters reported a rise in shares of Acambis and Bavarian Nordic, who may make additional doses of vaccine for the US Department of Health and Human Services.

\section{Pfizer Australia is fined for misleading promotion of celecoxib}

Bob Burton Canberra

Pfizer Australia has been fined for breaching the drug industry's own marketing code of conduct over a letter it sent to health professionals defending the safety of celecoxib (Celebrex) after the recall of rofecoxib (Vioxx) last year.

In a letter that Pfizer sent out in October the company said that "the cardiovascular safety profile of Celebrex has been extensively studied" and that "the data do not indicate significant cardiovascular safety concerns with Celebrex." Pfizer wrote of the study on the long term safety of celecoxib in arthritis that "there was no increase in serious cardiovascular thromboembolic events in patients on Celebrex who were or were not also taking prophylactic low-dose aspirin."
In November 2004 Dr Peter Mansfield, the then director of the Australian watchdog group Healthy Skepticism, complained to Medicines Australia, the body representing the drug industry, that Pfizer's letter breached the industry's voluntary code of conduct. He argued that Pfizer had misled doctors by understating the cardiovascular risks of celecoxib, as there had been no adequate long term study of potential cardiovascular events associated with celecoxib.

In January 2005 Medicines Australia's code of conduct appeals committee determined that Pfizer had breached the code's provision requiring promotional material to "be current accurate, balanced and [that it] must not mislead either directly, by implication, or by omission."
The committee imposed a fine of $\$$ A25 000 ( $£ 10370 ; \$ 18960$; $€ 15080)$ and directed that a corrective letter be sent to all recipients of the original letter.

In May 2005 Pfizer's appeal against the decision was dismissed. In its review the committee determined that as the letter could "have had a major effect on prescribing and possible safety implications, it should be considered a severe breach."

Pfizer also argued that a corrective letter was unnecessary and could generate confusion. The committee decided that a corrective letter would "be futile" because of the time elapsed since the original letter and because product information sheets on celecoxib sent to prescribers had been later amended to upgrade warnings on cardiovascular risks.

Dr Mansfield said the fine is insignificant in comparison with the $\$ A 100 \mathrm{~m}$ worth of celecoxib that Pfizer sold in Australia in 2003-4. "They have failed to require a retraction, so doctors who were misled will continue to harm people by prescribing Celebrex inappropriately," he said.

Overturning the need for a corrective letter, he said, highlighted a flaw in the self regulatory system. The decision, he said, would allow companies "to evade retractions" by pursuing the lengthy appeals process and arguing that corrective letters would cause confusion.

In 2003 Pfizer Australia was fined a total of $\$$ A20 000 for two breaches of the code relating to its promotion of sildenafil (Viagra). In 2004 Pfizer was found to have breached the code on three occasions and was directed to withdraw promotional material.

The media affairs manager for Pfizer Australia, Mr Craig Regan, said that although the company was disappointed it accepted the committee's decision. Overturning the need for a corrective letter, he said, was partly due to there being a number of other letters the company had sent to health professionals subsequent to the one complained about. 